\title{
AN ECONOMIC ANALYSIS OF CONTROLING AND REDUCING WATER POLLUTION IN JUJRUD RIVER THROUGH WILLINGNESS-TO- PAY (WTP) DETERMINATION METHOD
}

\author{
Komeil Jahanifar \\ Zahra Abedi \\ Yaghoob Moridzadeh \\ Faculty of Environment and Energy, Islamic Azad University (IAU), \\ Science and Research branch, Tehran, Iran
}

\begin{abstract}
This research will economically investigate and analyze water pollution control and reduction in Jajrud River from Jajrud and Megon River's intersection to Latian barrier valve through calculating WTP quantity using contingent valuation method (CVM). The WTP to maintain the present quality of the river's water and also to improve water quality were calculated using questionnaires and face-to-face interviews with beneficiaries (native people and tourists). Results revealed that the average WTP to maintain the present quality was 11 Euros at fishing activity level, 8.5 Euros at tourism level and 6 Euros at drinking or agriculture level. On the other hand, the WTPs to improve water quality in fishing, tourism and farming sections were $1.65,14$ and 7.5 Euros respectively.
\end{abstract}

\section{KEYWORDS}

Valuation, Willingness to pay, Water pollution, Jajrud River

\section{INTRODUCTION}

Supporting and protecting the environment has a close relationship with the economic and political issues; however, conflict and paradox might exist between these two advantages i.e. the environment and political-economic issues in some cases. However, reducing pollution and the harmful effects created in the environment at a reasonable level in the process of sustainable development along with a balanced use of advanced technologies has been always important in maintaining and ensuring health, growth and the survival of organism of the Earth in present and future in a way that it is one of the factors affecting survival on the earth is a biological access to fresh water [2]. With the increasing demand for water deposits in recent years, the pollution of rivers, lakes and other water resources are more than anything else [5]. As the current trend continues, water will probably turns into an important issue for a violent competition and international tension, which should be considered as a main factor for continued cooperation and communication with the modified method of operation and preventing from wasting and polluting it [3]. Optimized utilization of water resources and preventing from polluting water resources and renewable sources is one of the challenges for

https://doi.org/10.15626/Eco-Tech.2010.103 
development. Surveys show that the use and management of water resources are not desirable in most countries especially Iran and a variety of problems and failure in this regard are observed now. Limited water resources and centralized population, agriculture and industry centers in the country's border of water resources, particularly in recent years, the process of using water resources exacerbate the consequences of their activities and these resources are subjected to various threats has interactively in a way that inattention to this issue can cause the country's development process to face serious obstacles and bottlenecks in near future. Due to the limited water resources and the aggravation of the country's need for different sectors, providing water for various uses is one of the main challenges for the government to achieve sustainable development and therefore refining and re-using as major orientations should be considered in next decade in line with policies to prevent pollution of water resources and control pollutants, use water resources efficiently, prevent implementation of laws and regulations to protect water resources (see Table 1).

Table 1) Water consumption in Iran and the country's water needs and programs and favorable scenario in the country's water master plan in 2020

\begin{tabular}{|c|c|c|c|c|c|c|}
\hline \multirow{2}{*}{ Consumptions } & \multicolumn{2}{|c|}{1995} & \multicolumn{2}{c|}{2000} & \multicolumn{2}{c|}{2020} \\
\cline { 2 - 7 } & Amount & Percent & Amount & Percent & Amount & Percent \\
\hline $\begin{array}{c}\text { Drinking and } \\
\text { sanitation }\end{array}$ & 4.5 & 5.2 & 6 & 6.4 & 7.8 & 6.9 \\
\hline $\begin{array}{c}\text { Industry and } \\
\text { mining }\end{array}$ & 0.9 & 1 & 1.1 & 1.2 & 2.4 & 2.1 \\
\hline Agriculture & 81.4 & 93.8 & 86 & 92.4 & 103 & 91 \\
\hline Environment & - & - & - & - & 5 & - \\
\hline Total & 86.8 & 100 & 93.1 & 100 & 113.2 & 100 \\
\hline
\end{tabular}

Amounts to billion cubic meters

Using the contingent valuation method in this study, the amount of public willingness to pay has been calculated to control and reduce water pollution in Jajrud River, which is the tourist and recreational region of the northeastern Tehran.

\section{METHERIALS AND METHODS}

In the study of the economic analysis and study of water pollution control and reduction from Jajrud and Megon River's intersection to Latian barrier valve through calculating WTP, we have tried to use the methods and theoretical foundations of environmental economics including the contingent valuation method to answer fundamental questions. After conclusion, this research could be regarded as an economic analysis to adopt an approach for the prevention and control of pollutant sources entering the river Jajrud. Jajrud River basin with an area equivalent to 69,000 ha in geographical position of $51^{\circ} 05^{\prime \prime}$ to $51^{\circ} 24^{\prime \prime}$ east longitude and $35^{\circ} 46^{\prime \prime}$ to $36^{\circ} 03^{\prime \prime}$ width is located in the north of Tehran. The average annual precipitation is about $6300 \mathrm{~mm}$. The average daily temperature is about 15 degrees centigrade and annual rainfall catchment (over a period of 35 years of statistics) is a minimum of 370 $\mathrm{mm}$ and $1100 \mathrm{~mm}$ in the maximum years. The most important water resource of the area can be rivers, waterfalls, springs and underground resources feeding Jajrud River. The river full of water and beautiful waterfalls and springs along the heights covered with unique plant 
diversity caused more than 3500 people to spend time from neighboring cities for leisure time on weekends with their families in the catchment every day. In recent years, lots of places and facilities have been established and utilized to facilitate visiting the spot and providing recreational and facilitating equipments. [1]. since people are the main consumers of public environmental services of Jajrud River and suffer the greatest loss from its pollution, the statistical research community includes people who use the services of environmental River. In order for the research direction in the involved population to be based on random sampling, was have tried to collect data in a comprehensive form as possible. To this end, according to the exploiters of the river, which include native and nonnative people, two categories were used for statistical community. The first group consists of tourists and visitors and the second group includes service and reception units in the riverbank. To determine the number of community and provide statistical confidence of more than 95 percent in the questionnaire, the below formula has been used (see Equation 1):

$$
n=\frac{N \cdot t_{2} \cdot S_{2}}{t_{2} \cdot S_{2}+N d_{2}}
$$

In this formula:

$\mathrm{n}$ : Number of samples required

$\mathrm{N}$ : Total number of samples available in the community

$\mathrm{t}_{2}$ : Distribution of $(\mathrm{t})$

$\mathrm{S}_{2}$ : Sample variance

$\mathrm{d}_{2}$ : Statistical error

Finally, 500 questionnaires were filled by the statistical community group and 57 questionnaires to the number of income units (units based catering and restaurant on the sidelines of the river) and selected after completing the final stage of Pre-Test questionnaire was conducted.

In this study, since contingent valuation method based on a hypothetical market is used and the result directly depended on objectivity, accuracy and precision with completed questionnaires, therefore, several key steps were noted in completing questionnaires.

1 - At first, the subject was introduced to the responder and its importance was explained for him to provide favorable field for the correct answer to the questionnaire [4].

2 - After a clear and appropriate definition of environmental goods and various aspects of its application was provided for the responder, the environmental services of Jajrud River such as fishing, enjoying the beautiful landscape, taking as drinking water and as the source of income were mentioned with regard to priority in their selection by selecting one to four for the highest priority and lowest priority of preference (preference) to clarify his priority.

3 - Surveys about satisfaction or dissatisfaction accountability of current water quality in rivers as well as services related to the extraction principles that are the basis for their willingness to pay were located. This question would lead to different groups of respondents to be classified. Considering this, the participants should give the highest priority number one and number four to the lowest priority was to reveal their preferences, this review encountered $\mathrm{P}=4$ ! $=24$ modes. Finally, the first and second group questionnaires within were completed 6 months in different seasons and has been analyzed by SPSS software. 


\section{RESULTS AND DISCUTION}

Results from surveys in the two groups have been studied:

\subsection{Community and tourist visitors to the area studied}

The questionnaire of the first group comprises three sections. Part one: profile, second person's awareness of active service units, restaurants and especially the effects on water quality in rivers and Jajrud; next, monthly income and the key question, much like the person paying for the project to control and reduce water pollution Cross-rivers and Megon Jajrud Latian Dam exit. Preliminary results obtained from responders include the following:

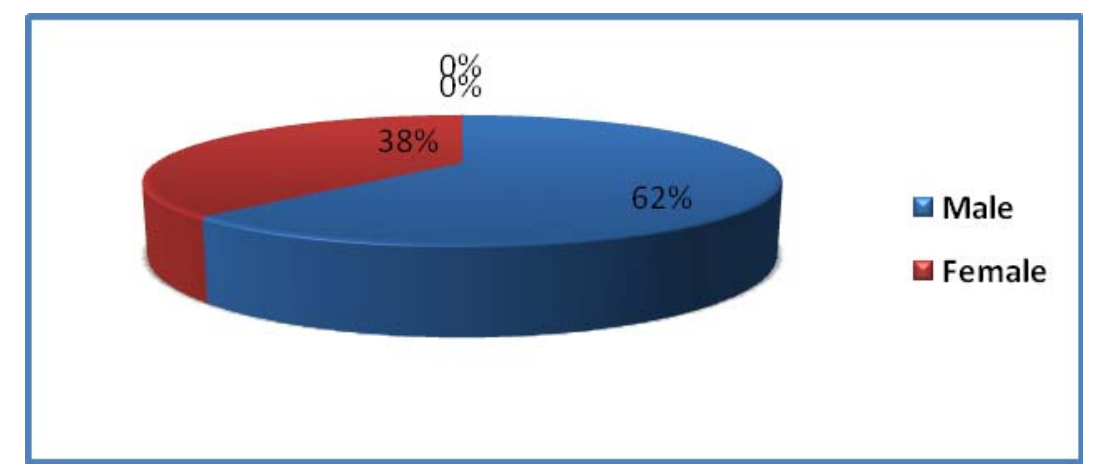

Fig 1) Respondent's genus

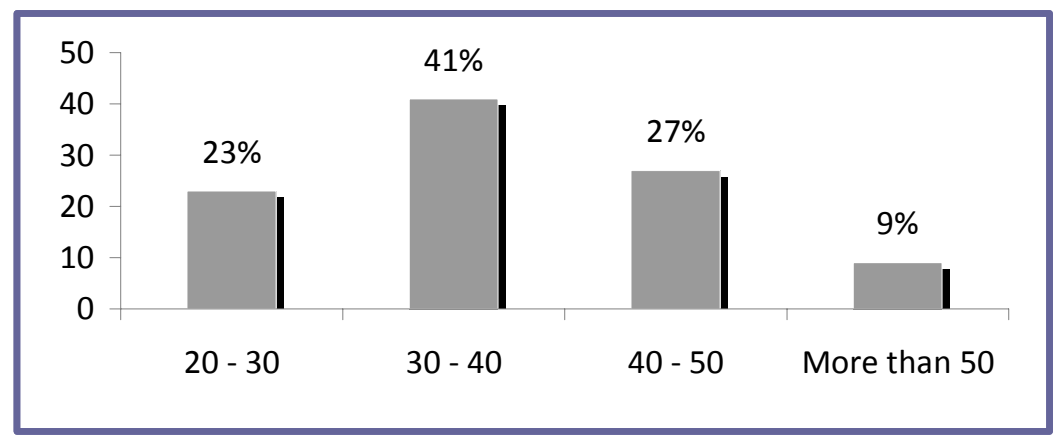

Fig 2) State age 


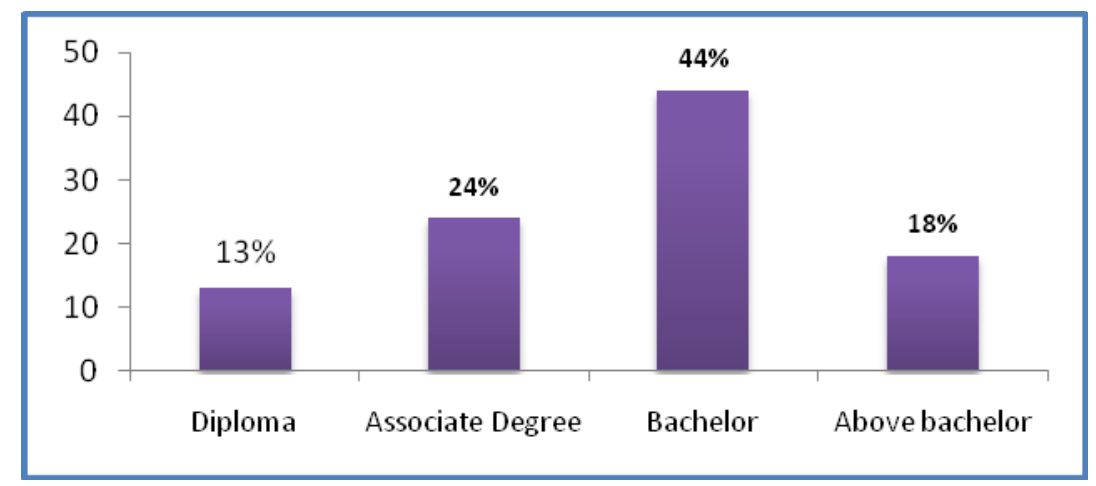

Fig 3) Respondent's education

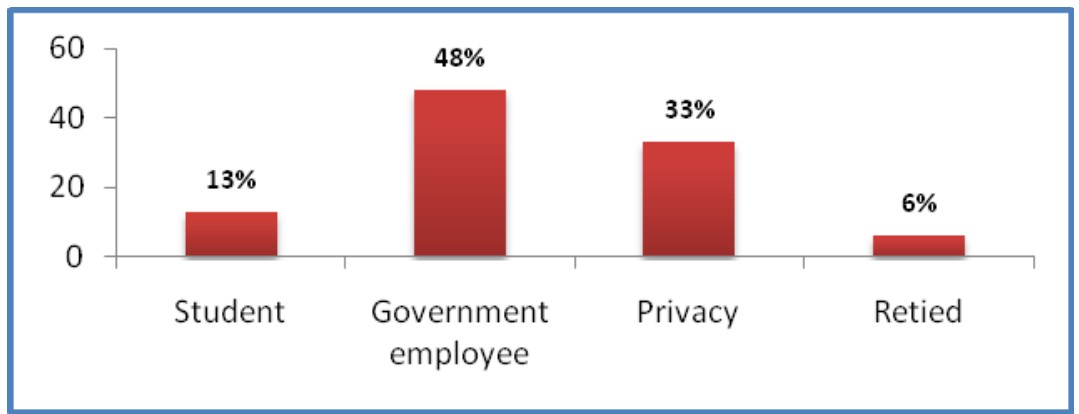

Fig 4) Job status

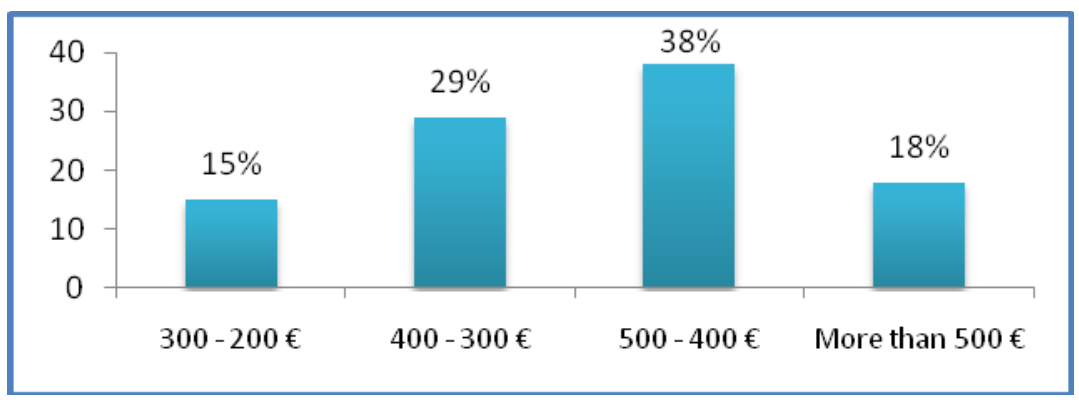

Fig 5) State the monthly income

From the above graphs, the dominant perspective of consumer goods and visitors environmental study area can be obtained. Most visitors were men with 30-40 years age group (see Fig 1), (see Fig 2) with university education (see Fig 3) and equivalent income account for 400-500 Euros (see Fig 5). Over 70 percent of the units include catering and camp visitors with the recreational use of river margins, while more than 65 percent of visitors entering pollution (sewage and garbage), resulting from the activities of units into the river, have observed. In the survey, 37 percent were indifferent to this issue, 41 percent of the organizations and relevant agencies reported 22 percent of the units, and pollutants are reminded that these results indicate a high turnout in reducing river pollution. Then, the region of 500 visitors and natives asked is whether you like as a citizen to maintain current water quality and prevent pollution from entering the catchment have a share, 78.5 percent 
positive and 21.5 percent have a negative answer to this action and knew the responsibility for administration and affiliated organizations. People, who were willing to participate and met monthly during the year, were ready to pay an amount to control and reduce water pollution or to pay adequate drinking water and take advantage of entertainment such as boating and fishing. Payment rates for the Jajrud River statistical community environment monthly chart is shown below (see Fig 6):

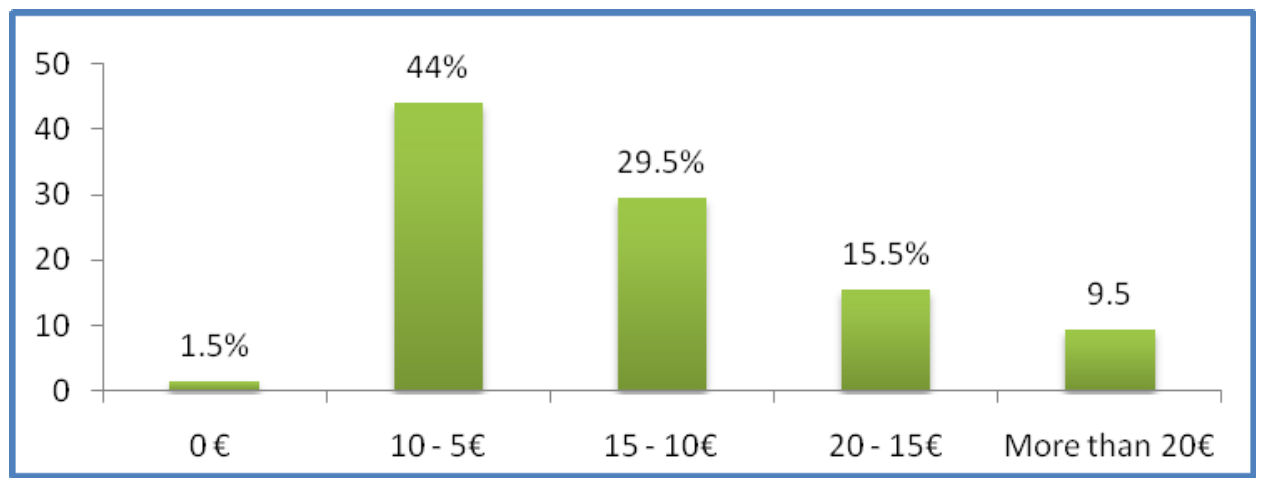

$\mathrm{Fi}$

g 6) Monthly Payment for maintaining Jajrud River's environment by visitors

It was clear in the survey that the most pollution about the criterion of statistical community perspective and negative effects that pollution has on regional $\mathrm{TV}$, has been paying little attention to environmental pollution were so close to 40 percent of pollution (sewage and waste) were indifferent to their surroundings and this should show people in the field of environmental knowledge and necessary training is given.

\section{2 community service-catering units stationed on the sidelines of the river:}

Because the number of service units based in the margins of all the little river community ( 57 units) were questions related to survey research, this questionnaire had 15 questions, which have been divided into two categories. Thus, the question regarding the 11-unit profile and cost requirements for the prevention and control of pollution entering the river and the rest of the owners of units for desire continue at the current location. After collecting completed questionnaires from the statistical community and review information obtained the following results:

1 - More than 62 percent of restaurants and catering units with up to 10 years old have four.

2 - About 14 percent of catering units, 86 percent leased and the rest is private property.

3 - The Number of visitors and customers catering units per week were averagely between 100 and 150 respectively.

4 - The amount of daily water consumption of the catering units, about 25-35 cubic meters are.

5 - About 58 percent of effluent from the units of activity through the creation of River (Creek) River, 8 percent Septic tanks built into 34 percent of the city by tankers are collected and emptied.

6 - Construction and maintenance cost of a tank in a unit catering Septic is roughly between 3000 - 4500 Euros. 
7 - Water supply from the river, all the units that Jajrud or through wells or tap directly into the river and the residential units are welcome.

8- 100 percent catering units stationed on the sidelines and riverbed was licensed health business, but only about 8 percent of them in terms of environmental compliance regulations, have the environmental certification.

9 - About 63 percent of the units and side effects and diseases caused by direct entry, without purification of wastewater and sewage into the river restaurants Jajrud do not think they know their own water cleanup does and only 37 percent compared to the same illnesses and diseases resulting from drinking and agriculture water pollution were aware.

10 - According to the results obtained from questionnaires completed by restaurants and catering units, 76 percent of active units and the willingness to cooperate and participate in the reduction and control of water pollution in particular are studied area and 19 percent abstained Topic and only 5 percent declared nope.

11 - According to the results, the rate of payment reception units that has a positive view on this issue, the chart is shown below (see Fig 7):

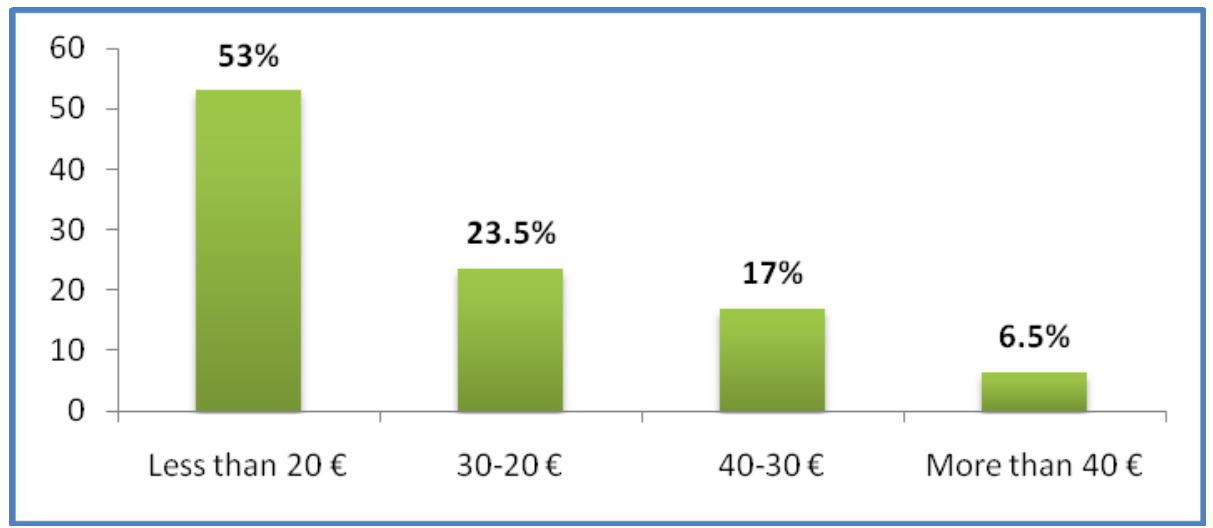

Fig 7) Monthly Payment for maintaining Jajrud River's environment by service catering units

The above graph shows the proposed fee increase to pay rates tend to reduce river pollution is reduced Jajrud and this result is not far-fetched. Willingness to pay much more interest and visitors eyes! Maintaining the current quality of water for fishing activities, types of tourism and agriculture and drinking water were calculated and questioned (see Table 2).

Table 2) Average willingness to pay people to maintain water quality in different parts of Jajrud

\begin{tabular}{|c|c|c|c|}
\hline No. & Willingness To Pay (WTP) & $\begin{array}{c}\text { Avera } \\
\text { ge }\end{array}$ & $\begin{array}{c}\text { St.deviati } \\
\text { on }\end{array}$ \\
\hline 1 & Willingness to pay in order to maintain quality fishing & 10.73 & 22.34 \\
\hline 2 & $\begin{array}{c}\text { Willingness to pay to maintain any level of quality in tourism } \\
\text { activities }\end{array}$ & 8.55 & 12.38 \\
\hline 3 & $\begin{array}{c}\text { Willingness to pay in order to maintain the quality of drinking } \\
\text { and agriculture water use }\end{array}$ & 6.16 & 10.44 \\
\hline
\end{tabular}


On the other hand, amount willingness to pay to improve water quality at three levels listed was calculated in the table is shown below (see Table 3):

Table 3) Average willingness to pay people to improve river water quality in different parts of Jajrud

\begin{tabular}{|c|c|c|c|}
\hline No. & Willingness To Pay (WTP) & $\begin{array}{c}\text { Avera } \\
\text { ge }\end{array}$ & $\begin{array}{c}\text { St.deviati } \\
\text { on }\end{array}$ \\
\hline 1 & Willingness to pay in order to improve quality fishing & 16.52 & 12.35 \\
\hline 2 & $\begin{array}{c}\text { Willingness to pay to improve any level of quality in tourism } \\
\text { activities }\end{array}$ & 14.19 & 10.08 \\
\hline 3 & $\begin{array}{c}\text { Willingness to pay in order to improve the quality of drinking and } \\
\text { agriculture water use }\end{array}$ & 7.67 & 11.94 \\
\hline
\end{tabular}

\section{CONCLUSIONS}

As noted, the purpose of this study was willingness to pay in the eyes of visitors and benefiting from environmental goods and services in Jajrud River. This point is always clear that the side effects of pollution on the one hand reduces the service aspects and the other river water quality for drinking purposes, fishing, enjoying the scenery of river and other inappropriate entertainment offers. It is notable in the study that due to concerns that regional restructuring due to the influx of tourists and travelers in this region become good climate and the tourist area is created. Area around the river and changed into a promenade Jajrud, causing unwanted contamination entering the water resources and water quality is low. All polls indicate public participation to prevent and reduce pollution host. Of the main reasons for this can be the high literacy level in the eyes of visitors and benefiting the region noted. Educated people, mostly ages 30- 40 years old in order to better understand the maintenance and protection of environmental goods and services are. Another point is that income levels and significant direct relationship with the amount of willingness to pay to maintain and improve river water quality has had. Willingness to pay the amount of the people who have monthly income more than lower-income people who have been most is that these results are not farfetched. Community group in the statistical results showed that over 70 percent of visitors are willing and capable to 200 Euros for environmental river Jajrud pay. The second group recreational and restaurant owners are more willing to help maintain quality of the river. Over 80 percent of them are willing to pay 30 Euros to assign it. This reason can be pointed out that the group's career and future income directly depends on the quality and river health because it causes no pollution hits the people of this region. Comparison chart of the amount willingness to pay to maintain and improve the quality of river water quality is considered Jajrud willingness to pay to maintain the water quality of rivers Jajrud willingness to pay much to improve the quality of people much less. The result could be due to the People always improve a quality of satisfaction they get more to prevent such an unpleasant event contamination.

Considering the last results of the study, we offered some suggestions:

- Recommended that government officials before adopting and implementing any policy, especially regarding the establishment and activities of any unit in the riverbed and margins of Jajrud, first the aspects necessary studies conducted by the relevant 
experts to be justified from the perspective of environmental economics it can be determined.

- Recommended that the executive program to collect network and wastewater treatment in the form of population centers (LOCAL) is accelerating.

- Recommended that the monitoring prohibition imposed on the construction and implementation of Jajrud river basin master plan approvals exact prevent and reduce pollution of river water with the aim of maintaining water quality to be intensified Jajrud.

- It is suggested that the location of solid waste in the catchment area and discharge Jajrud done any domestic and industrial wastes in rivers and privacy to prevent the main branches. While considering the potential range studied tourism and resorts in the area, widespread use is necessary to manage solid waste in priority conservation area will be placed.

\section{REFRENCES}

[1] Amirnejad, H., S.Khalilian.2005.Estimating the tourist value of national park, Golestan and determination effective variables on willingness to pay of individuals. The $5^{\text {th }}$ Iranian conference on agriculture economics, pp 89-101

[2] Desvousges, W.H., Smith, fisher, A., 2004. Option price estimates for water quality improvements: A contingent valuation study for the Monongahela River, Journal of environmental economics \& management, (12) pp 121-129.

[3] Emadi kohi, A., K. Jabberi., 2005-2006.Economic Valuation of water resources of Fars province, Journal of Environmental science and technology, (15) P 33-41.

[4] Ghorbani, M., A. Firuzzare., 2007.Introduction to Valuation of Environment. Ferdowsi Mashhad University Press, (1): p 57-59.

[5] John. A. Adjaye., 2002.Environmental Economics for Non- Economists. Translated by: S.Dehghanian and Z.Faradjzadeh, Ferdowsi Mashhad University Press, (2): pp135- 141. 